\title{
The Role of Greek Shipowners in the Revival of Northern European Shipyards in the 1950s
}

\section{Gelina Harlaftis and Christos Tsakas}

\section{Introduction}

Greece continues to be the largest shipowning country in terms of cargocarrying capacity (309 million dwt), followed by Japan, China, Germany and Singapore. 'Together, these five countries control almost half of the world's tonnage. ${ }^{1}$ In the immediate post-World War II years Greek shipowners managed to become major players in world sea transport. By entering the oil shipping market they became leaders in the tanker business. Led by Aristotle Onassis, the first Greek to invest in newlybuilt tankers before the war, prominent shipowners like Stavros Niarchos,

${ }^{1} \mathrm{UNCTAD}(2017,28)$.

G. Harlaftis

Rethymnon, Greece

C. Tsakas $(\varangle)$

Princeton University, Princeton, NJ, USA 
Stavros Livanos, the Kulukundis-brothers and the P. Goulandris-brothers became United States' main shipping partners, carrying much of its foreign trade. During the 1950 s they all launched massive shipbuilding programmes and became catalysts for the revival of the war-torn European shipyards, and particularly of the West German and British ones along with those of Belgium, Sweden, France and the Netherlands. As shipping has always been important in geopolitics, this was as much about business as it was about politics.

The US policy-makers often attempted to take advantage of the Greeks' dominant position in the independent tanker industry, either using them as scapegoats for their internal policies or stressing the crucial role they could play in regional Cold War crises in their foreign policy. From accusing them of 'red trade' during the Korean war, fraud during the change of government from Democrats to Republicans in 1954, to imposing embargo on Cuba in the aftermath of Fidel Castro's revolution in 1960s, Greek shipowners occasionally became the focal point of US diplomatic efforts. ${ }^{2}$ Seeking safe refuges in times of crisis, had been a constant objective for Greek shipowners since the early 1950s. After their dispute with the US authorities during the 1950s they all shifted their focus to Europe and ended their brief stay in New York. ${ }^{3}$ Apart from Britain, one of their main maritime centres since the nineteenth century, the Federal Republic of Germany (FRG) became their new maritime entrepreneurial target, where they launched massive shipbuilding programmes that revived the war-torn German shipyards. Haakon Ikonomou and Christos Tsakas, by addressing the responses of Greece and Norway to the Common Shipping Policy efforts in the 1960s and the 1970s, have recently shown how two leading maritime nations from the outer periphery reacted to, and largely influenced, the integration dynamics of the shipping sector at the regional European level. ${ }^{4}$ Our study will also give some insights on the potential contribution of business and maritime history into scholarly debates on

\footnotetext{
${ }^{2}$ Foreign Relations of the United States (hereafter FRUS), 1958-1960, VI, 980-991 (545) and FRUS, 1964-1968, XVI, 174-179 (82).

${ }^{3}$ Harlaftis (2014).

${ }^{4}$ Ikonomou and Tsakas (2019).
} 
the role of pre-existing international business networks in the process of European integration. ${ }^{5}$

As this volume indicates, shipping was both an example and an engine of globalization and structural change in the post-war era. This chapter builds on the recent work of Michael Miller, who has highlighted how the Europeans ran the maritime business world in the twentieth century and has located shipping in the prevailing historical narrative of global business, and of Gelina Harlaftis, who has indicated how the Greeks created global shipping business in the twentieth century. ${ }^{6}$ Harlaftis examines the choices of Greek shipowners, led by Aristotle Onassis, who were able to exploit the opportunities given by the oil companies in the United States in the 1940s and led the way in tanker shipping in Europe. ${ }^{7}$ Greeks were able to establish the new institution of the global shipping company, a kind of multinational company, that was based in many countries and used Panamanian and Liberian companies and flags which meant that it was taxed under the law of these countries. They served the ever-increasing oil industry by contracting long-term charters with American oil companies and by using finance from American banking institutions to invest initially in American but later more in northern European shipyards.

Miller has largely focused on liner shipping, whereas the Greek shipowners were involved in tramp and bulk shipping. ${ }^{8}$ Tramp and bulk shipping made possible a global supply line for basic resources like food, energy and raw materials for the industry. Greeks in the South of Europe, often under Flags of convenience, proved a prime example of the evolution of the regional European maritime businesses to serve the global economy. In fact, one could safely argue that the history of modern bulk and tramp shipping simply cannot be written without them. Miller's focus, however, on the shipping infrastructure as a key component of the industry's globalizing effect, points to an interesting direction for further research. Hamburg, one of the big European ports Miller studies, became synonymous for the German shipyards along with a few other shipbuilding hubs,

\footnotetext{
${ }^{5}$ Ramirez Perez (2010) and Rollings and Kipping (2008). For a recent account, see Tsakas (2018). ${ }^{6}$ Miller (2012) and Harlaftis (2019).

${ }^{7}$ Carlisle (1981).

${ }^{8}$ See Stopford (1997) for an introduction to the distinctions between the various segments.
} 
such as Bremen and Kiel. These industrial hubs were targeted by Greek shipowners. Aristotle Onassis was the first to turn to the war-torn German shipyards and revive them, thus contributing to the 'German economic miracle', known as Wirtschaftswunder. Across the Channel the war-struck British shipbuilding industry built an even larger amount of tanker tonnage for leading Greek shipping companies like the Kulukundis brothers, Stavros Livanos and Stavros Niarchos.

The shipbuilding industry reflected wider transformations in shipping that led to the present-day globalized economy. We examine how Greek shipping entrepreneurship, American finance and northern European technical know-how triggered the revival of European shipyards and the continuation of European hegemony in global shipping in the 1950 s and thereafter. Greek shipowners were able to promote technological advancements in European shipbuilding that were diffused globally and transformed the global tanker industry. This is the story of a rare twentieth century reversal of roles. In the post-World War II period in the case of shipping and shipbuilding, southern Europe helped revive not only northern European shipbuilding, but also became the mainstay of European shipping to the present day.

\section{Why the Greeks?}

Greek shipowners after World War II were able to take advantage of the major transformations that took place in the shipping markets and in world leadership. During this period, three important changes took place that changed the maritime world. The first was the shift from coal to oil as a main energy source, and as a main commodity to be carried. The second was the shift from the political hegemony of Great Britain to that of the United States. The third was the use of offshore companies and flags of convenience which Greeks were among the first to adopt and set the pace for the creation of the global shipping firm which was not connected to one nation.

If the history of the maritime transport of power in Europe in the first half of the twentieth century was written by coal and tramp ships, in the second half it was written by oil and tankers. The 1950s was the critical 
decade for this transition. In 1900 oil was an insignificant source of energy; world production of 20 million tons met only $2.5 \%$ of world energy consumption. Because production was so limited there was little need for specialized vessels; tankers, mostly owned by Europeans, accounted for a tiny $1.5 \%$ of world merchant tonnage. By 1938 oil production was 273 million tons per year and accounted for $26 \%$ of world energy consumption. ${ }^{9}$ But it was after 1945 that oil became the primary energy source worldwide; by 1970 it had risen to a peak of $56 \%$. Another very important change was that although before the Second World War the United States was the world's leading oil producer, by 1948 it became a net importer for the first time. In the 1950s Middle Eastern production surged and major US oil companies (Chevron, Esso, Gulf, Mobil and Texaco) and two European firms (Shell and BP) dominated production, distribution and sales around the world, except in the socialist countries. Between 1953 and 1973 the volume of seaborne oil increased by six times to almost two billion tons, amounting to about $60 \%$ of all maritime trade. This enormous increase went alongside an unprecedented demand for tanker tonnage. ${ }^{10}$

After the end of World War II the US possessed the largest fleet of merchant ships in the world, with $60 \%$ of world tonnage, compared with 1939 when it was about $14.5 \% .{ }^{11}$ Due to alarming ship losses during the war, the United States through the United States Maritime Commission (USMC) had launched a massive shipbuilding programme through which 4694 ships of all kinds, both commercial and military were built. ${ }^{12}$ Despite the enormous fleet, the United States was not able to support this fleet as it had not been able to develop a maritime tradition equivalent to that of Britain or provide internationally competitive maritime services. After the war the American officials were thus faced with the huge problem of what to do with this enormous and costly fleet that was six times larger than needed, with ships that were mostly of a rather older technology and were too costly to be operated by American shipowners. In the end, American

\footnotetext{
${ }^{9}$ Eden et al. (1981).

${ }^{10}$ Ratcliffe (1985).

${ }^{11}$ Perry (1946).

${ }^{12}$ Achee-Thornton and Thomson (2001).
} 
policymakers decided to sell two-thirds of the fleet and to form a reserve fleet with the rest. In March 1946 President Truman signed the Merchant Ship Sales Act which authorized USMC to sell government-owned vessels to domestic and foreign shipowners. ${ }^{13}$ There were however, a number of restrictions on the types of vessels available to foreigners, for example tankers were not available for sale to foreigners, only in specific cases and limited numbers. ${ }^{14}$

The Greeks were among the first to purchase such ships, in particular the famous 'Liberty' type that were medium-sized cargo ships. ${ }^{15}$ In 1939, the Greek merchant fleet consisted of 1.8 million grt but by 1946 only 500,000 grt remained. The sale of Liberty ships was a great opportunity for Greek shipowners to acquire new ships on highly favourable terms. On 9 April 1946, the Greek government guaranteed the purchase of 100 Liberties on behalf of its shipowners, with long-term loans from the American banks with the obligation to hoist the Greek flag. Another 300 vessels of the USMC merchant fleet were purchased by Greek shipowners in cash or with loans provided by American banks and under the condition that they would hoist the so-called 'flags-of-convenience'. ${ }^{16}$

The Flags of convenience as they came to be called in the 1950s became a key manifestation of American maritime policy led by American oil companies that needed low-cost transport. This came as a result of the shift of political power and influence from Britain to the United States after 1945 which ushered in a new era in world shipping. 'Flagging out' from traditional registers to Flags of convenience became a major feature of postworld war II international shipping. The Flags of convenience of Panama, Honduras and Liberia-known as the PanHoLib fleet-were part of the trend to turn to offshore companies. This solution not only provided an economic shelter, like cheap flags with low taxes, but also flexibility beyond state control in a global environment. ${ }^{17}$ When a sealift was needed, the

\footnotetext{
${ }^{13}$ More on the review in Hutchins (1951).

${ }^{14}$ Marx (1948).

${ }^{15}$ Sawyer and Mitchell (1973).

16 Naftika Chronika, 1 April 1946 and 15 April 1946; Harlaftis (1996, 2013) and Tzamtzis (1984).

${ }^{17}$ See Cafruny (1987); the fleets were also referred to as PanLibHon. For a classic on Flags of convenience, see Metaxas (1985). For the resort of the Greeks to Flags of convenience, see Harlaftis (1989).
} 
PanHoLib would immediately become the United States' allies, and the American Navy could forcibly requisition this fleet. Thus in the second half of the twentieth century, the United States was able to 'rule the waves' by this tacit policy, that started in the interwar period and culminated in the 1940s and 1950s. ${ }^{18}$ Consequently, 'America's hegemonic ascendancy was expressed not through supplanting the European powers and filling the oceans with American flag vessels but rather through constructing a system in which the European merchant fleets could flourish but in which core American interests were safeguarded'. ${ }^{19}$

Greek shipowners were able to exploit the opportunities offered in the United States better than did their main competitors, the Norwegians, who were handicapped by their state's decision to restrict and finally prohibit purchase of foreign vessels in 1949-1950. Norwegians were among the world's main tanker owners in the interwar period and the decision by their state handicapped their international business. ${ }^{20}$ It was the Greeks that filled the space. They engaged the U.S., the world's new economic power, as their main trading partner, as they had done with Great Britain in an earlier period. This was the advantage of cross-traders and of tramp owners: By serving international trade rather than the needs of a particular nation, they were able to adjust to changes in the world environment. ${ }^{21}$ They were able-and also encouraged by the American credit institutions that financed them - to take advantage of the situation serving simultaneously both American and their own interests.

Among the prime movers of this trend were Aristotle Onassis and a group of Greek shipowners established during World War II in New York. Onassis was among the first to (a) establish the new institution of the global shipping company, a kind of multinational company that was based in many countries and used Panamanian and Liberian companies and flags which meant that it was taxed under the law of these countries; (b) serve the ever-increasing oil industry by contracting long term charters; (c) provide finance from American banking institutions to invest

\footnotetext{
${ }^{18}$ A prime example of an American 'invisible billionaire', Daniel Ludwig. See Shields (1986). For the use of Flags of convenience by American shipowners, see de la Pedraja (1992).

${ }^{19}$ Cafruny $(1987,87)$.

${ }^{20}$ Tenold (2019, 150-151).

${ }^{21}$ Harlaftis (1993, 43-46).
} 
in shipbuilding, and (d) turn from the American to European shipyards triggering development in the war-torn shipyards of Germany, Britain, France, Belgium, Netherlands and Sweden. Alan Cafruny has argued that 'in formal terms, Flags of convenience are the result of foreign direct investments by multinational companies or independent bulk carrier operators', citing Onassis among the prime examples of the latter category. ${ }^{22}$ The use of Flags of convenience was very much frowned upon in the European traditional maritime nations even as late as the 1980s. This practice which paved the way to the global shipping company broke the so-called 'genuine link' between the ship's flag and the nationality of its owner. But this was part of the irreversible globalization trend. By the mid-1980s, however, a quarter of the fleet of the European Community's members were flying flags of convenience. ${ }^{23}$ The next sections will reveal the foreign direct investments of Greek shipowners in the German, British and other European and non-European shipbuilding industry concentrating in tankers. In doing so, we contend that the Greek shipowners, acting as a bridge between global and local dynamics, transformed not only the maritime industry, but also the shipping infrastructure of the ports where they established offices, and, most importantly, networks.

\section{Building Tankers in European, American and Asian Shipyards}

Greeks were involved in both dry and liquid cargoes but it was the latter and particularly oil and the entrance in the tanker market that brought the apogee. During the decade 1950-1960 they were able to build an extraordinary tanker fleet of 268 tankers, almost $50 \%$ of which in the European shipyards. More specifically, as is evident in Table 8.1, Britain and Germany attracted $77 \%$ of the Greek shipowners' orders of tankers in European shipyards followed by those of Sweden, the Netherlands, Belgium, France and Yugoslavia. They built 127 tankers in Europe; to this number of ships, one has to add an equally large, and even larger, number of cargo

\footnotetext{
${ }^{22}$ Cafruny $(1987,91)$.

${ }^{23}$ Tenold et al. $(2012,11)$.
} 
Table 8.1 Tankers built by Greek shipowners in European, American and Asian shipyards, 1948-1960

\begin{tabular}{lrrrrrr}
\hline Place of shipyards & No. of ships & \multicolumn{1}{l}{$\%$} & \multicolumn{1}{l}{ grt } & \multicolumn{1}{l}{$\%$} & \multicolumn{1}{l}{ nrt } & $\%$ \\
\hline Total Europe & $\mathbf{1 2 7}$ & $\mathbf{4 7}$ & $\mathbf{1 , 9 4 5 , 5 3 7}$ & $\mathbf{3 9}$ & $\mathbf{3 , 0 2 9 , 8 1 7}$ & $\mathbf{3 7}$ \\
Great Britain & 60 & 47 & 831,581 & 43 & $1,278,028$ & 42 \\
Germany & 38 & 30 & 641,536 & 33 & $1,019,441$ & 34 \\
Sweden & 9 & 7 & 160,677 & 8 & 250,817 & 8 \\
Netherlands & 7 & 6 & 96,244 & 5 & 145,067 & 5 \\
Belgium & 5 & 4 & 81,581 & 4 & 128,638 & 4 \\
France & 4 & 3 & 74,644 & 4 & 117,786 & 4 \\
Italy & 3 & 2 & 45,939 & 2 & 70,069 & 2 \\
Yugoslavia & 1 & 1 & 13,335 & 1 & 19,971 & 1 \\
Total America and & $\mathbf{1 4 1}$ & $\mathbf{5 3}$ & $\mathbf{3 , 0 0 7 , 4 9 6}$ & $\mathbf{6 1}$ & $\mathbf{5 , 1 0 8 , 6 6 3}$ & $\mathbf{6 3}$ \\
$\quad$ Asia & & & & & & \\
Japan & 92 & 65 & $1,967,679$ & 65 & $3,205,102$ & 63 \\
USA & 46 & 33 & 976,540 & 32 & $1,805,596$ & 35 \\
Canada & 3 & 2 & 63,277 & 2 & 97,965 & 2 \\
General total & $\mathbf{2 6 8}$ & $\mathbf{1 0 0}$ & $\mathbf{4 , 9 5 3 , 0 3 3}$ & $\mathbf{1 0 0}$ & $\mathbf{8 , 1 3 8 , 4 8 0}$ & $\mathbf{1 0 0}$ \\
\hline
\end{tabular}

Source Lloyd's Register of Shipping, 1948-1960; Ioannis Theotokas and Gelina Harlaftis, "Pontoporeia 1945-2000", unpublished database, see Theotokas \& Harlaftis

ships. They thus revived the war-torn shipyards of northern Europe. The American shipyards that saw their heyday in the years immediately after the war until the beginning of the 1950s received less than one-eighth of the total orders of tankers. It was the Japanese shipyards that was the new rising Asian player indicating the trend that was to follow in the world shipbuilding industry. The European shipyards received more of their orders during the Korean war, in the first half of the 1950s whereas the Japanese shipyards thereafter.

As the British shipbuilding industry was the most important before World War II and Greek shipowners held representative shipping offices in London since the nineteenth century it was only natural that in Europe most of the orders would be placed with the British shipyards. ${ }^{24}$ The shipyards of Furness Shipbuilding Co., Ltd., in Hartlepool, and of VickersArmstrongs Ltd., in Newcastle on the river Tyne in north-eastern England, provided more than half of the production of tankers. The rest were built in other eight British shipyards; in Scotts' Shipbuilding \& Engineering Co.,

${ }^{24}$ Johnman and Murphy (2002). 
Ltd., in Blythswood Shipbuilding Co. Ltd. and in Fairfield Shipbuilding \& Engineering Co on the river Clyde in Scotland; in Sir James Laing and Sons Ltd., in William Doxford \& Sons Ltd. and Bartram \& Sons Ltd., in Sunderland, Smith's Dock Co. Ltd., in North Shields and W. Gray \& Co. Ltd. in West Harlepool, all in northeastern England. In France in the Societé des Ateliers et Chantiers de France in Dunkirk and Chantiers \& Ateliers de St. Nazaire-Penhoët, S.A. at St. Nazaire, in the Ateliers \& Chantiers de la Seine Maritime (Worms \& Cie) in Trait in north-western France, and in Chantiers Navals de La Ciotat in La Ciotat in southern Mediterranean France. In Sweden they built tankers in Kockums Mekaniska Verkstads Aktiebolag in Malmö and in Uddevallavarvet Aktiebolag in Uddevalla, both in southern Sweden. In the Netherlands, in Nederlandsche Dok \& Sheepsbouw Maatschappij V.O.F. in Amsterdam and in N.V. Wilton Fijenoord Dok-en Werf Maats in Rotterdam. In Belgium in J. Boel \& Fils and in the Societé Anonyme Cockerill-Ourge and in Italy in the Cantieri Riuniti dell' Adriatico in Trieste. In Germany the three big North Sea ports hosted the largest German shipyards Howaldtswerke A.G. in Hamburg and Kiel and A.G. Weser in Bremen. All the above were traditional long-term business establishments that had built most of the world's fleet carrying an established know-how and tens of thousands of workers. With a large number of shipyards almost destroyed during the war, the flow of orders for advanced technology vessels, backed up with American finance which Greeks secured, contributed to the northern European industrial development.

The 'big five' or the so-called 'golden' Greeks, were the ones that invested in more than 20 tankers each, namely Aristotle Onassis (35 tankers), Stavros Niarchos (40 tankers), Kulukundis brothers (32 tankers), Stavros Livanos (31 tankers) and Petros Goulandris' sons (24 tankers) (see Table 8.2). Other Greek shipowners that ordered about ten tankers each were C.M. Lemos (12 tankers), N.J. Goulandris' sons and Carras. Shipowners like Andreades, Vergottis, Embiricos, Nomicos, Chandris, Lykiardopulo, Papadakis invested in between five and seven tankers and another 18 shipowners in between one and three tankers. All Greek shipowners that ordered tankers were traditional shipowners, meaning that they were second, third or fourth generation into the shipping business. Their families hailed from the traditional Greek shipping islands of Andros 


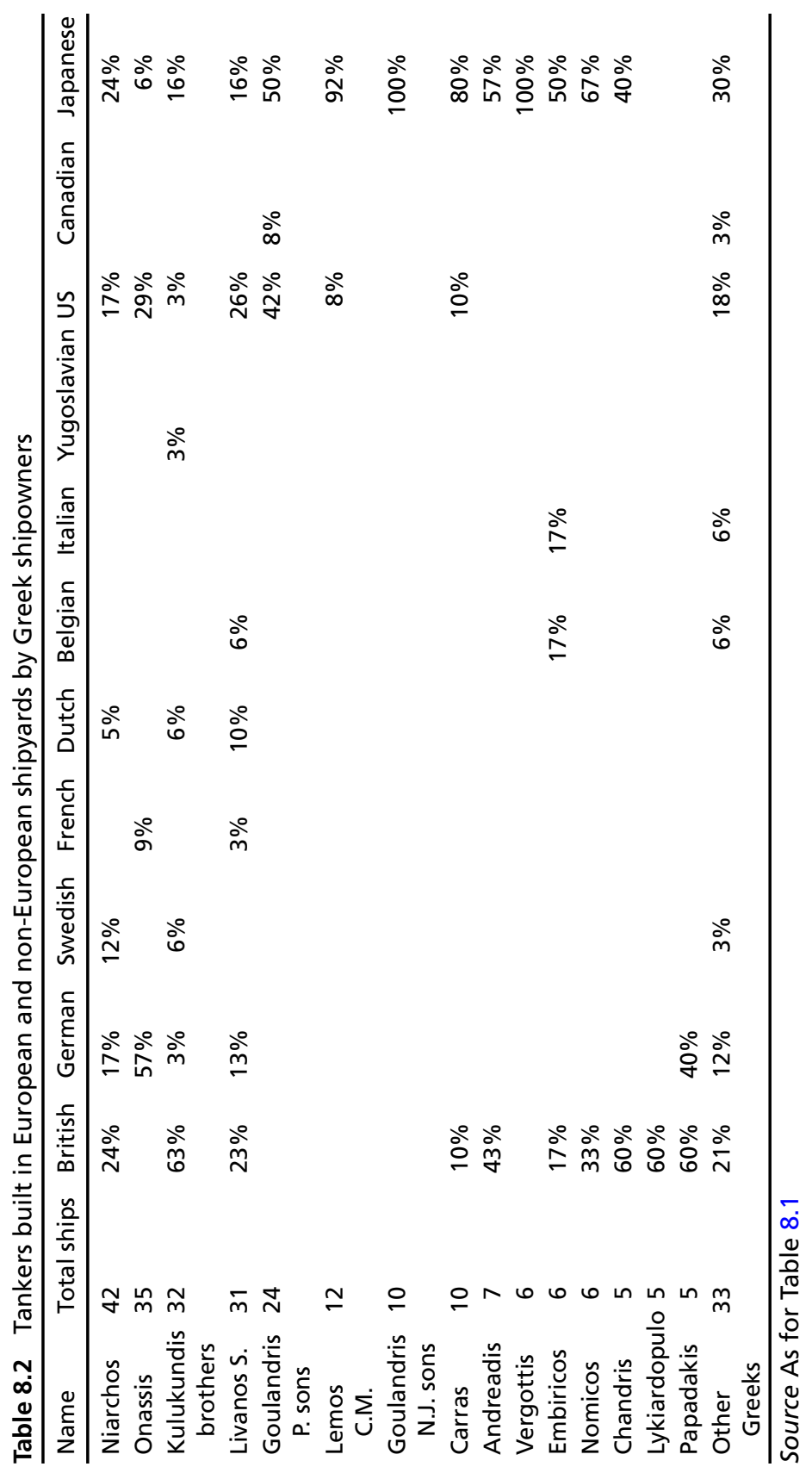


(Goulandris, Embiricos), Kasos (Kulukundis, Papadakis), Cephalonia (Vergottis, Lykiardopulo), Chios (Livanos, Chandris, Carras) and Santorini (Nomicos). The only newcomers in the business were in fact Aristotle Onassis and Stavros Niarchos.

Aristotle Onassis led the way. In the immediate post-World War II era, ensuring a large tanker fleet under the U.S. flag with second-hand vessels from the war-built American fleet, Aristotle Onassis proceeded at the same time into a large shipbuilding programme. For his newbuildings, he firstly turned to the American shipyards, which desperately needed clients after an intensive period of extraordinary shipbuilding during the war. The first tanker Onassis built after the war was in the American Sparrow Point Shipyards in Bethlehem. It was of 11,298 grt and 18,151 dwt, about $3000 \mathrm{dwt}$ bigger than his three Swedish tankers, built almost ten years earlier. Olympic Games, delivered in 1948 launched his famous 'Olympic' fleet. Another five tankers were delivered in 1949 and 1950 by the same shipyard; these were much bigger, 28,000 dwt.

In 1951, Onassis turned to European shipyards. The main reason was that he saw an upcoming conflict with the United States government, which was not hospitable anymore to foreign shipowners. ${ }^{25}$ In 1951, the FBI had started investigations into his shipping business in New York and his purchases of American tankers from the United States Maritime Commission. This culminated in February 1954, when he was sued by the United States government, for 'illegal purchases' of tankers from the United States Maritime Commission. ${ }^{26}$ Stavros Niarchos and the Kulukundis brothers and others were equally accused and sued. As the American government could not make a case of illegal purchases and take to court the Greek shipowners, at the end, settlement agreements were arranged for all. As Rodney Carlisle has argued it was probably the case that Greeks were used as scapegoats by American politicians, a buffer for the internal problems caused by the American shipping businesses and seafarers that saw foreigners like the Greeks and foreign companies like offshore companies take over America's external trade. ${ }^{27}$ This policy was

\footnotetext{
${ }^{25}$ Harlaftis (2014).

${ }^{26}$ Harlaftis (2014).

${ }^{27}$ Carlisle (1981) and Harlaftis (2019).
} 
not at all in accordance with the interests of American shipyards. In fact, as Daniel D. Strohmeier, the vice-president of the American Bethlehem yard said to the press prophetically on the event of the launching of Niarchos' World Glory, 'Merchant shipbuilding in this country will be all finished by the end of this year. Our situation would be brighter if our public servants in Washington would devote as much energy in helping us to cultivate foreign shipbuilding as they do in driving it away through legal harassment'. ${ }^{28}$

The conflict between the U.S. government and Greek shipowners was a watershed. The Greeks, who were turning to New York as their new and rising entrepreneurial shipping base, all turned their back to the United States and the American shipyards. They proceeded to launch massive shipbuilding programmes in the European shipyards and the newly emerging Japanese ones. The four top Greek shipowners, Onassis, Niarchos, Kulukundis and Livanos, built more than two thirds of their tankers in northern European shipyards. The rest of the Greek shipowners built on average $38 \%$ of their fleet in Europe (see Table 8.2 ). The only exception was the group of companies of Petros Goulandris' sons who built half of their tanker fleet in the United States and the other half in Japan.

By building most of their tankers in British, Dutch, Swedish, French and Belgian shipyards, Greeks followed pre-existing business networks. What is interesting to see here is the turn to the German shipyards. Henry Burke Wend, addressing the early post-war US policy regarding the future of the West German shipbuilding industry, has detailed its shift from the politics of dismantling through reconstruction to prioritizing rearmament. This shift, made possible due to major Cold War considerations, largely contributed to making the shipyards one of the largest exporting industries in the Federal Republic of Germany. Wend's focus on US high politics, however, has left the role of business actors understudied. Who made this shift possible? Moreover, his investigation of the shipyards under US control (namely the shipyards in Bremen, including AG Weser, one of the biggest shipbuilding firms) has excluded the shipyards of the British-controlled ports in Hamburg and Kiel. ${ }^{29}$ It was the German-Greek business networks that have been left out until now in the debate on the Wirtschaftswunder.

\footnotetext{
${ }^{28}$ Quincy launches largest tanker. 1954. The New York Times, 10 February 1954, 31.

${ }^{29}$ Wend (2001).
} 
In 1954, with 963,114 dwt, the West German shipbuilding industry was a major contributor to the German economy, representing over 18\% of the world shipbuilding production, second only to Great Britain. ${ }^{30}$ The West German shipbuilding industry ranked second to none in terms of export intensity, as foreign contracts represented $54 \%$ of its total production. ${ }^{31}$ Furthermore, two West German shipyards, Deutsche Werft and Kieler Howaldtswerke, were on the top of the list of the biggest shipyards of the world. ${ }^{32}$

This dynamic growth, which even came to threaten the British supremacy, ${ }^{33}$ had not been the case for a long time. In 1952, with 520,172 dwt overall production, the West German shipyards ranked third in the world, representing $11.84 \%$, just above the USA and Sweden (10.64 and $10.34 \%$ of world production respectively), ${ }^{34}$ whereas in 1950 the shipbuilding production in the newborn Federal Republic of Germany barely exceeded 150,000 dwt. ${ }^{35}$ Labelled as the 'forbidden industry', shipbuilding suffered strict restrictions under the Allied controls, and it was not before November 1949 that the Petersberg Agreement lifted most of them, paving the way for its development. ${ }^{36}$ Still, German shipyards were in need of capital inflows and in search of contracts and German shipping was able to provide them neither the former nor the latter. Moreover, the war-devastated German shipyards faced not only market dominance from British, the US and Swedish shipyards, but also the French, Italian and Japanese competition.

It was Onassis that made the difference. When in 1951, Onassis turned his back to the American shipyards he targeted the German shipyards for tanker shipbuilding. He brought back to life the shipyards of Hamburg, Bremen and Kiel introducing an amazing shipbuilding programme financed by the New York City Bank of New York. In three years, the three

\footnotetext{
30 Schiff und Hafen, 5, May 1955.

${ }^{31}$ Schiff und Hafen, 5, May 1955. Jahresbericht des Bundesverbandes der Deutschen Industrie 1 Mai 1954-30. April 1955, May 1955 and Schiff und Hafen, 2, February 1955.

32 Schiff und Hafen, 4, April 1955.

33 The New York Times, 19 July 1954.

${ }^{34}$ Schiff und Hafen, 5, May 1954.

35 Schiff und Hafen, 9, September 1955.

${ }^{36}$ Boie (1993).
} 
Western German shipyards, Howaldtswerke (Hamburg), Howaldtswerke (Kiel) and A.G. Weser (Bremen) built 18 tankers for him; these were mostly tankers of 21-22,000 dwt. Onassis' orders represented $85 \%$ of the Kieler Howaldtswerke tonnage, $62 \%$ of the AG Weser and $67.5 \%$ of the Howaldtswerke Hamburg tonnage delivered in $1954 .{ }^{37}$ These shipyards ranked second, third and fifth respectively in the Federal Republic of Germany and were the second, ninth and 18th top shipyards in the world respectively regarding their production in $1954 .{ }^{38}$ These figures show that Onassis's orders literally revived from ashes the war-torn German shipyards, boosting not only their building capacity and employment in the industry, but also technological innovation. The great technologic achievement of the German shipyards and Onassis's technical team received worldwide attention. The launching of the biggest tankers in the world at the time, signalled the transition to ship gigantism.

The size of tankers exploded between the late 1940s and the 1970s. The aim was to achieve economies of scale; the larger the tanker, the lower the cost of transport, the higher the profits. Such economies of scale would not have been possible without shipbuilding technological advancements. These also related to the speed of loading and discharging operations. There were further improvements in the engines, in the design of hull, in propulsion, in the introduction of the bulbous bow, in rudder, in navigation aids, and in hull paints, etc. Technical advances were made inside the hull too; gradually automation reduced the number of crew from over 50 to about 30 seamen. In an interaction of shipyard-shipping company, Greeks contributed to the advancement of tanker ship technology. Among them, Aristotle Onassis was a pioneer. He was the first Greek shipowner to invest in tanker newbuildings before World War I. He was a great believer in European shipbuilding. His first tanker was the Ariston, of 15,360 dwt, which was ordered from a Swedish shipyard; it was one of the biggest and technologically advanced tankers of its time.

\footnotetext{
${ }^{37}$ Our calculations include only ships over $4000 \mathrm{dwt}$. The relevant list published by Schiffund Hafen, 4, April 1955.

${ }^{38}$ Ibid.
} 
Ownership of huge ships became a struggle of prestige among the large tanker owners. The tanker that Onassis built ten years later, in 1949, was almost double the size: Olympic Flame, 28,385 dwt in the USA. The newspapers in the 'new' and 'old' world were full of articles on shipbuilding in American and European shipyards. The 'invisible millionaire', the American Daniel Ludwig who owned the company National Bulk Carriers had built in the American shipyards five tankers of 30,000 dwt by 1948 . In 1952 the New York Times presented a tanker 'champion' of 32,500 dwt, the World Enterprise built by Vickers-Armstrongs in Newcastle-upon-Tyne. But the reign of the new champion was doomed to be short-lived. ${ }^{39}$ Two years later, the German shipyards of Hamburg were in all the news on 24 July 1953 when the largest tanker in the world, Tina Onassis, of 46,080 $\mathrm{dwt}$, for which the term 'supertanker' was coined, was launched. The term introduced a new type of tanker that was between 50-70,000 dwt, at the time. It was only superseded by Onassis' Al-Malik Saud Al Awal, of his ill-fated Saudi Arabian Tankers Co; the supertanker that hoisted the Saudi Arabian flag for a few years was of 47,130 dwt. ${ }^{40}$ It was 1104 feet long, high as twelve-storey building. ${ }^{41}$

Onassis continued building supertankers in the German shipyards and his Olympic Challenger built in 1960 was 64,750 dwt. As larger ships kept being built, the industry invented more superlatives like the 'mammoths' of 100,000 dwt ${ }^{42}$; Onassis' 'mammoth' Olympic Fame was built in 1965 in French Shipyards. When there were no other superlatives, the ships of above 200,000 dwt were called Very Large Crude Carriers (VLCCs) in the late 1960 s.

Stavros Niarchos and Manolis Kulukundis tried to surpass Onassis' glory in the German shipyards and built new supertankers themselves. Other traditional Greek shipowners like Stavros Livanos, Diamantis Pateras, Lyras Bros and newcomers like Marchessini also ordered in the German shipyards. But most of the Greek shipowners, including Stavros Niarchos, ordered their ships in Great Britain and in order to fulfill the rapidly

\footnotetext{
${ }^{39}$ The New York Times, 27 September 1952.

${ }^{40}$ Harlaftis (2019, Chapter 7).

${ }^{41}$ The New York Times, 4 June, 1954.

${ }^{42}$ Ratcliffe (1985, 19-20).
} 
Table 8.3 Loans from American banks for ships purchased, 1949-1959

\begin{tabular}{lllll}
\hline $\begin{array}{l}\text { Dates of } \\
\text { purchase }\end{array}$ & Type of ship & $\begin{array}{l}\text { Type of } \\
\text { purchase }\end{array}$ & $\begin{array}{l}\text { Number of } \\
\text { ships }\end{array}$ & $\begin{array}{l}\text { Loans } \\
\text { (\$Million) }\end{array}$ \\
\hline $1949-1954$ & Tankers & Newbuildings & 30 & 46.6 \\
$1958-1959$ & Tankers & Newbuildings & 6 & 17 \\
Total loans & & & 36 & 63.6 \\
\hline
\end{tabular}

Source Harlaftis (2019, Table 7.6)

increasing demand for oil transport spread their shipbuilding activities to the Swedish, French, Dutch and Belgian shipyards.

The largest number of the tankers built in European shipyards hoisted the PanHoLib flags. After the international boycott of 1958 against flags of convenience and particularly Panamanian and Honduran flags, Onassis, like the rest of the Greeks, mainly used in his Olympic fleet of tankers the Liberian flag. From 1948 to 1960, he had built 35 tankers, 30 of which, of the latest technology, and of the largest size, were built in Europe. ${ }^{43} \mathrm{He}$ raised 64 million dollars from the American banks, most of which were channelled in Europe and particularly to Germany (Table 8.3). Equal amounts were drawn by the other leading Greek shipowners, like Stavros Niarchos, from American banks to be invested in the European shipyards.

According to moderate estimates, processing the data compiled by the West German journal Schiff und Hafen (which was based on diverse sources), Onassis's share in total orders in German shipyards $(1,791,000$ dwt) in January 1953 was $24.54 \% .{ }^{44}$ Onassis's contribution to the revival of West German shipyards is even more impressive in terms of his share in the shipbuilding production. In 1954 West German shipyards launched 11 tankers for Onassis's companies totalling to $250,685 \mathrm{dwt}$. That is to say that Onassis's share in the West German shipbuilding production that year $(963,114 \mathrm{dwt})$ was 26\%. Moreover, his share in the West German total production of tankers (444,000 dwt) was $56.46 \%$, whereas his share in the West German production of tankers for foreign shipping companies $(380,216 \mathrm{dwt})$ was $65.93 \% .^{45}$

\footnotetext{
${ }^{43}$ Table 8.3 is based on Harlaftis (2019, Table 7.6).

${ }^{44}$ Schiff und Hafen, 11, November 1955.

45 Schiff und Hafen, 5, May 1955 and 9, September 1955.
} 
Onassis' relationship with the German shipbuilding industry originated in the close contacts he had developed with Hamburg since late 1940s for his whaling fleet. It was then that he saw the war-devastated shipyards, the wasted know-how of thousands of workers and shipping engineers, and grabbed the opportunity. Before placing his first orders of tankers in Kieler Howaldtswerke in early 1951, this shipyard had delivered 15 converted whaling ships to Onassis in 1950 (see Table 8.4). ${ }^{46}$ Those ships represented a substantial part of the first post-war orders in Howald tswerke Kiel. Onassis had met Adolph Westphal, the director of Howaldtswerke, thanks to the Norwegian shipowner Anders Jahre, ${ }^{47}$ but Onassis and Howaldtswerke seem to have forged an independent business alliance. Certain attributes typical of maritime business networks between shipowners and builders, such as mutual trust and preference at equal prices, ${ }^{48}$ seem to apply in this case. The story of the twin supertankers Onassis ordered in Howaldtswerke is most telling: Celebrating the launching of some of his ships in the Kieler Howaldtswerke, Onassis asked Westphal about the costs of building one supertanker and the shipyards director gave a rough estimate. Shortly afterwards, Onassis ordered a twin supertanker, but Westphal asked an amount well above his initial estimate, claiming he had played down the costs in the first place. Though surprised, Onassis placed the second order as well, without further bargaining. ${ }^{49}$

Howaldtswerke were not the only shipyards Onassis maintained close links with. Dr. Kurt W. Reiter, a key figure in the Olympic Maritime, Onassis's agency in Hamburg, had been the first post-war director of AG Weser, Bremen. Furthermore, Onassis was not the only shipping tycoon of Greek origin enjoying a special relationship with West German shipyards. Stavros Niarchos, with orders totalling to $130,000 \mathrm{dwt}$ in Kieler Howaldtswerke and 32,500 dwt in Howaldtswerke Hamburg in late $1952,{ }^{50}$ promised further orders in German shipyards in 1954,

\footnotetext{
46Boie (1993). Table 8.4 is based upon data from Lloyd's Register of Shipping, 1950-1956. Onassis Business Archive, Alexander S. Onassis Foundation, Minutes of Balleneros Ltd S.A., 1949-1951.

${ }^{47}$ Harlaftis (2014).

${ }^{48}$ See Boyce (2003).

${ }^{49}$ Boie (1993, 61-62).

50 Schiff und Hafen, 11, November 1952.
} 
Table 8.4 The Onassis whaling fleet

\begin{tabular}{|c|c|c|c|c|c|}
\hline Name of ship & Flag & $\begin{array}{l}\text { Type of } \\
\text { vessel }\end{array}$ & grt & Date of built & $\begin{array}{l}\text { Date of } \\
\text { purchase }\end{array}$ \\
\hline $\begin{array}{c}\text { Olympic } \\
\text { Arrow }\end{array}$ & Honduras & Whaling & 702 & 1944 & 1950 \\
\hline $\begin{array}{l}\text { Olympic } \\
\text { Conqueror }\end{array}$ & Honduras & Whaling & 714 & 1940 & 1950 \\
\hline $\begin{array}{r}\text { Olympic } \\
\text { Chaser }\end{array}$ & Honduras & Whaling & 708 & 1941 & 1950 \\
\hline $\begin{array}{l}\text { Olympic } \\
\text { Cruiser }\end{array}$ & Panamanian & Whaling & 699 & 1943 & 1950 \\
\hline $\begin{array}{l}\text { Olympic } \\
\text { Champion }\end{array}$ & Honduras & Whaling & & & \\
\hline $\begin{array}{l}\text { Olympic } \\
\text { Explorer }\end{array}$ & Honduras & Whaling & 699 & 1942 & 1950 \\
\hline $\begin{array}{l}\text { Olympic } \\
\text { Fighter }\end{array}$ & Honduras & Whaling & 712 & & 1950 \\
\hline $\begin{array}{l}\text { Olympic } \\
\text { Hunter }\end{array}$ & Honduras & Whaling & 715 & 1941 & 1951 \\
\hline $\begin{array}{l}\text { Olympic } \\
\text { Lightning }\end{array}$ & Honduras & Whaling & 702 & & \\
\hline $\begin{array}{l}\text { Olympic } \\
\text { Rider }\end{array}$ & Honduras & Whaling & 717 & 1940 & 1951 \\
\hline $\begin{array}{l}\text { Olympic } \\
\text { Promoter }\end{array}$ & Honduras & Whaling & 699 & 1942 & 1950 \\
\hline $\begin{array}{l}\text { Olympic } \\
\text { Runner }\end{array}$ & Honduras & Whaling & 715 & 1940 & 1950 \\
\hline $\begin{array}{c}\text { Olympic } \\
\text { Tracer }\end{array}$ & Honduras & Whaling & 406 & 1949 & 1951 \\
\hline $\begin{array}{l}\text { Olympic } \\
\text { Victor }\end{array}$ & Honduras & Whaling & 702 & 1944 & 1950 \\
\hline $\begin{array}{l}\text { Olympic } \\
\text { Winner }\end{array}$ & Honduras & Whaling & 744 & 1942 & 1951 \\
\hline
\end{tabular}

Source Gelina Harlaftis (2019). Creating Global Shipping: Aristotle Onassis, the Vagliano Brothers and the Business of Shipping, c. 1820-1970. Cambridge: Cambridge University Press Table 7.3; based on Lloyd's Register of Shipping, 1950-1956. Onassis Business Archive, Alexander S. Onassis Foundation, Minutes of Balleneros Ltd S.A., 1949-1951

in case they offered equal prices with their Swedish rivals. ${ }^{51}$ Niarchos's orders in the Federal Republic of Germany had not been on the same level with those of Onassis, but their concentration in Howaldtswerke and preference at equal prices imply the existence of network relations

${ }^{51}$ Handelsblatt, 41, 7 April 1954. 
between shipowner and builder. One should note that Stavros Niarchos had a similar shipping business group to Aristotle Onassis. By 1950 they both owned more than 50 vessels each, mainly tankers of about half a million gross registered tonnage. ${ }^{52}$

\section{Greek Shipowners, European Shipyards and International Politics}

In Germany, Onassis and Niarchos attempted to extend this network alliance to an investment or ownership tie. As early as 1951, Onassis and Niarchos, participating in a consortium with German firms, bid for the state-owned Howaldtswerke. ${ }^{53}$ The purchase of Howaldtswerke became a disputed issue within the federal government and a swift privatization proved impossible. Despite his meeting with Konrad Adenauer and considerable support from certain advisors of the Chancellor, Onassis failed to strike a deal due to opposition of the German finance minister, Fritz Schäffer. ${ }^{54}$ Major concerns included the possibility of losing control to foreigners, cutting production capacity and the resulting unemployment in a labour-intensive industry. ${ }^{55}$ Moreover, although taking over both Howaldtswerke Hamburg and Howaldtswerke Kiel would be very expensive, the viability of the next best option, their split and the purchase of the premises in Hamburg and Kiel separately, was questionable. After his failure to jointly buy the Kieler Howaldtswerke with Onassis, Niarchos offered a DM 15 million loan to the Kieler Howaldtswerke to take over

\footnotetext{
${ }^{52}$ For Onassis's fleet, see Harlaftis (2019, Appendix 2B). For Niarchos fleet, see The Career of Stavros Niarchos. 1952. Naftika Chronika, April 15.

${ }^{53}$ Scholz to Kattenstroth, Howaldtswerke AG, 4 December 1951 and the attachment Bundesministerium der Finanzen (BMF), Veräusserung der Aktien der Howaldtswerke AG, Hamburg, 29 November 1951, Bundesarchiv Koblenz, B102/15552.

${ }^{54}$ CIA to State, Efforts of Onassis to purchase German ship works, 5 August 1954, CIA, Nazi War Crimes Disclosure Act (FOIA)/ESDN (CREST): 519a2b7b993294098d50ffcd; Hamburger Anzeiger, 4 May 1954, Bundesarchiv Koblenz, B108/5149.

${ }^{55} \mathrm{BMF}$ to Bundeskanzleramt, Verkauf der Howaldtswerke Hamburg AG Hamburg, 19 August 1954 and the attachment Verkauf der Howaldtswerke Hamburg AG Hamburg, undated, Bundesarchiv Koblenz, B108/5149.
} 
Deutsche Werke Kiel, providing financial security to the whole project in exchange for participation in the governing board. ${ }^{56}$

The attempt by Onassis and Niarchos to purchase West German shipyards was an episode of a broader story with far-reaching implications. According to a CIA source, Robert Pferdmenges and Hermann Abs, top bankers close to Adenauer, intended to break the US-British control of oil and shipping fleets and influence Onassis projects with Arabs. ${ }^{57}$ Aristotle Onassis had signed with the Minister of Finance of Saudi Arabia El Suleiman and the full consent of King Saud on 20 January 1954 an agreement that brought a global turmoil that brought him against all the oil industry and many states. According to the agreement, which would come into effect on the 9 April 1954, Onassis obtained the right to carry all Aramco (Arabian-American Oil Company) oil in excess of that carried by Aramco's own tankers. Aramco's tankers carried about $10-20 \%$ of the total production. The agreement would prohibit the shipment of oil in chartered tankers of other nations. ${ }^{58}$

Although this was a business agreement, it was to be perceived as a threat and a counter attack to the US government, and it did just do that. This agreement went against the agreement of Aramco, the consortium of four large American oil Companies, Standard Oil of New Jersey, Standard Oil of California, Texas Company and Socony-Vacuum Oil Company, with Saudi Arabia, which had provided a monopoly of mining, refining and distribution of oil from 1933 to $2000 .{ }^{59}$

In this context, the launching of Al Malik Saud Al Awal in the Howaldtswerke Hamburg, was not just a coincidence. Yet, it was the Aramco case and its far-reaching implications that might have caused this purchase to fail. Although a CIA report, in August 1954, implied an ongoing cooperation between the Onassis and Niarchos, ${ }^{60}$ there was a falling

\footnotetext{
${ }^{56}$ Scholz to Graf, Kieler Hütte AG, 23 January 1953, Bundesarchiv Koblenz, B102/75949.

${ }^{57}$ CIA to State, Efforts of Onassis to purchase German ship works, 5 August 1954, CIA, Nazi War Crimes Disclosure Act (FOIA)/ESDN (CREST): 519a2b7b993294098d50ffcd.

${ }^{58}$ Harlaftis (2019, Chapter 7), based on 'Royal Government of Saudi Arabia. Memorial', Alexander S. Onassis Foundation, Onassis Archive, the Government of Saudi Arabia and the Arabian American Oil Company.

${ }^{59} \mathrm{FBI}$, 'Aristotle Onassis', part 4, Bufile 46-17783, Office Memorandum from A. H. Belmont to L. V. Boardman, 'Visit to Middle East and North Africa by Bureau's Army Liaison Representative', 16 June 1954. The Court at The Hague finally passed an agreement in 1958 in favour of Aramco. ${ }^{60}$ Ibid.
} 
out between Onassis and Niarchos particularly in the role the latter had played in the case of the US government vs Aristotle Onassis during this period. ${ }^{61}$

After their split and failure to purchase a shipyard in the Federal Republic of Germany, Onassis and Niarchos, seeking a secure environment they could use as a refuge in times of crisis, decided to invest heavily in Greece. In 1956 Stavros Niarchos established the Hellenic Shipyards and in 1957, he earned a concession for the ten-year operation of a newly built oil refinery, the only such establishment in Greece. At the same time Onassis secured a contract for the operation of Greece's airlines and created Olympic Airways, the only other private airline company after TWA. In the meantime, Onassis and Niarchos had clashed over the concession for the establishment of a big shipyard near Athens. Niarchos won the concession in collaboration with shipbuilders in the Netherlands. ${ }^{62}$ Although Onassis had placed emphasis on the Greek character of his investment in contrast with his rival's joint venture with a Dutch shipyard, ${ }^{63}$ he also sought technical support from a foreign shipyard, namely Howaldtswerke Kiel. ${ }^{64}$ Moreover, Onassis attempted to break Niarchos's alliance with the Dutch shipbuilders, using the previous network relations between him, Niarchos and the German shipbuilders, promoting a joint project with Niarchos's and Howaldtswerke's participation at the latter stage of the negotiations. ${ }^{65}$

Despite the failure of Onassis's project for the establishment of a shipyard in collaboration with Howaldtswerke in Greece, the importance of his proposal should not be neglected. The development of the Greek shipbuilding industry along with the development of other key industries such as the oil industry, chemicals and metallurgy was part of the industrialization and Europeanization strategy put forth by the Greek Prime Minister Constantinos Karamanlis for Greece's convergence with Europe's richest

\footnotetext{
${ }^{61}$ Harlaftis (2014).

${ }^{62}$ Ministry of Coordination, Chronicle of some major contracts, 7 April 1969, Nikolaos I. Makarezos Archive, Institute for Mediterranean Studies-Foundation for Research and Technology Hellas, Rethymno, F275/A; For relevant reportage, see O Oikonomikos Tachydromos (19 April, 17 May, 12 July, 2 August and 13 September 1956).

${ }^{63}$ O Oikonomikos Tachydromos, 17 May 1956.

64 The New York Times, 16 May 1956.

${ }^{65}$ O Oikonomikos Tachydromos, 2 August 1956.
} 
countries. In the formative years of European integration, German-Greek business relations and economic cooperation was a crucial factor that could enhance Greece's competitive advantages through industrial projects and joint ventures. From 1953 on, successive bilateral agreements had aimed at enhancing West German investments in Greek manufacturing and it was in 1958 with the Adenauer-Karamanlis agreement that this process was explicitly linked to Greece's European prospects. Furthermore, Greek shipping tycoons and their international business connections represented a potential source of capital of unique importance to a sluggish peripheral economy that had recently suffered a harsh Axis occupation and a devastating civil war. ${ }^{66}$

It is interesting to note that at the time that Niarchos purchased the Hellenic Shipyards Onassis turned to Britain. From 1957 onwards Aristotle Onassis started buying shares of the British shipyards in Ireland, Harland \& Wolff. By 1965 he had reached a total of $£ 1,180,032$ out of $£ 4,396,082$ representing $26.8 \%$ holding of the shipyards' capital. He tried to purchase the whole of the shipyards in the early 1970s with no success; by 1975 he owned one-fourth of the shares. ${ }^{67}$ Britain attracted more capital from Greek sources. The traditional shipowners Kulukundis brothers and their group of companies in 1957 purchased half of the shares of the Sunderland shipyards of Austin \& Pickersgiel. In April 1948, the Kulukundis brothers had founded together with Basil Emmanuel Mavroleon in London, the London and Overseas Freighters, one of the first independent private tanker companies based in Britain in the post-war period. In 1957 London and Overseas Freighters owned 50\% of the shares of Austin \& Pickersgill, and took over the whole company in 1970.

Far from just an episode in their dispute with US authorities in the aftermath of the Korean War, Onassis's and Niarchos's move from the United States to Europe and their heavy investments in Europe had broader implications both on a global and a local European level. On the global level on the one hand, they had challenged and overtaken the main European shipping entrepreneurs until World War II, the British, and on the other they had become the main international carriers of the new hegemonic

\footnotetext{
${ }^{66}$ Harlaftis (2008).

${ }^{67}$ Moss and Hume $(1986,416)$.
} 
power, the United States. On the European level, their primacy signalled the revival of the European shipyards. Their massive shipbuilding programmes brought Britain to the top of the list of export-intensive shipbuilding countries and second to the German shipbuilding industry, thus contributing to the German economic miracle. Moreover, they played a crucial role in the development of Greece's infant industries, establishing oil refineries, shipyards and airlines, that was an integral part of Karamanlis's industrialization strategy and sine qua non prerequisite for Greece's participation in European integration.

\section{Conclusions}

In the formative years of the immediate post-World War II period the European shipyards were in need of contracts and investment in order to increase their capacity and efficiency. The Greek shipowners offered them the American finance via the new global institutions they had adopted, offshore companies, and Flags of convenience. Almost all ships built were owned by Panamanian or Liberian companies. The flags hoisted on the vessels were Honduran, Panamanian or Liberian and ran by European crews. Their operating offices and agencies were in North and South America and in Europe. The choices they made were much talked about, frowned upon and at times received great animosity and slander. They chose to create their global shipping empires with offshore companies and flags of convenience and led the way to the global shipping business group that prevails the shipping industry today. Their choices in the 1940s and 1950s were new and unusual. Today they have become common practice in the global shipping business. European and world shipping was transformed in the post-World War II period. The 'new men' in Europe, who changed the face of world shipping and undertook European leadership, were involved in oil and tankers, belonged to the European periphery, they came from Greece and Norway. But it was businessmen from the South of Europe that led the way and helped the North to keep European primacy in global shipping. 


\section{Bibliography}

\section{Unpublished Sources}

Archives of the Federal Bureau of Investigation (FBI), 'Aristotle Onassis'. Bundesarchiv Koblenz, Germany: B102/15552, and B102/75949.

Bundesarchiv Koblenz, Germany: B108/5149.

Nikolaos I. Makarezos Archive, Institute for Mediterranean Studies-Foundation for Research and Technology Hellas, Rethymno, Greece.

Onassis Business Archive, Alexander S. Onassis Foundation, Athens, Greece.

\section{Published and Online Accessible Sources}

Central Intelligence Agency (CIA), Nazi War Crimes Disclosure Act (FOIA)/ESDN (CREST): 519a2b7b993294098d50ffcd. https://www.cia. gov/library/readingroom/. Accessed 30 June 2016.

Foreign Relations of the United States (hereafter FRUS), 1958-1960, VI.

\section{Press and Official Reports}

Handelsblatt.

Jahresbericht des Bundesverbandes der Deutschen Industrie 1 Mai 1954-30. April 1955.

Naftika Chronika.

O Oikonomikos Tachydromos.

Schiff und Hafen.

The New York Times.

UNCTAD. 2017. Review of Maritime Transport.

\section{Secondary Literature}

Achee-Thornton, R., \& Thomson, P. (2001). Learning from Experience and Learning from Others: An Exploration of Learning and Spillovers in Wartime Shipbuilding. The American Economic Review, 91(5), 1350-1368. 
Boie, C. (1993). Schiffbau in Deutschland 1945-52. Die verbotene Industrie. Bad Segerberg: Detlefsen.

Boyce, G. (2003). Network Knowledge and Network Routines: Negotiating Activities Between Shipowners and Shipbuilders. Business History, 45(2), 52-76.

Cafruny, A. (1987). Ruling the Waves: The Political Economy of International Shipping. Berkeley: University of California Press.

Carlisle, R. P. (1981). Sovereignty for Sale: The Origins and Evolution of the Panamanian and Liberian Flags of Convenience. Annapolis, MD: Naval Institute Press.

de la Pedraja, R. (1992). Rise and Decline of US Merchant Shipping in the Twentieth Century. New York: Maxwell Macmillan International.

Eden, R. J., et al. (1981). Energy Economics: Growth, Resource and Policies. New York: Cambridge University Press.

Foreign Relations of the United States (hereafter FRUS), 1958-1960, VI, 980-991

(545) and FRUS, 1964-1968, XVI, 174-179 (82).

Harlaftis, G. (1989). Greek Shipowners and State Intervention in the 1940s:

A Formal Justification for the Resort to Flags-of-Convenience? International Journal of Maritime History, 1(2), 37-63.

Harlaftis, G. (1993). Greek Shipowners and Greece, 1945-1975: From Separate Development to Mutual Interdependence. London: Athlone Press.

Harlaftis, G. (1996). A history of Greek-Owned Shipping: The Making of an International Tramp Fleet, 1830 to the Present Day. London: Routledge.

Harlaftis, G. (2008). Greek Shipowners and Constantine Karamanlis. In C. Svolopoulos, C. Botsiou, \& E. Hadzivassiliou (Eds.), Constantine Karamanlis in the Twentieth Century, International Conference, June 2007 (Vol. III, pp. 92-112). Athens: Constantine Karamanlis Foundation [in Greek].

Harlaftis, G. (2013). The "J'accuse" of Aristotle Onassis to the Shipowners and the Greek Government in 1947. Ionios Logos, 4, 325-400. [in Greek].

Harlaftis, G. (2014). The Onassis Global Shipping Business: 1920s-1950s. Business History Review, 88(2), 241-271.

Harlaftis, G. (2019). Creating Global Shipping: Aristotle Onassis, the Vagliano Brothers and the Business of Shipping, c. 1820-1970. Cambridge: Cambridge University Press.

Hutchins, J. G. B. (1951). United Merchant Marine Policy and Surplus Ships. Journal of Political Economy, 59(2), 117-125.

Ikonomou, H., \& Tsakas, C. (2019). Crisis, Capitalism and Common Policies: Greek and Norwegian Responses to Common Shipping Policy Efforts in 
the 1960s and 1970s. European Review of History. https://doi.org/10.1080/ 13507486.2019 .1592121$.

Johnman, L., \& Murphy, H. (2002). British Shipbuilding and the State Since 1918: A Political Economy of Decline. Exeter: University of Exeter Press.

Marx, D., Jr. (1948). The Merchant Ship Sales Act. The Journal of Business of the University of Chicago, 21(1), 12-28.

Metaxas, B. N. (1985). Flags of Convenience. London: Gower.

Miller, M. B. (2012). Europe and the Maritime World: A Twentieth-Century History. Cambridge: Cambridge University Press.

Moss, M., \& Hume, J. R. (1986). Shipbuilders to the World. 125 of Harland and Wolff, Belfast 1861-1986. Belfast and Wolfeboro, New Hampshire: The Blackstaff Press.

Perry, H. S. (1946). The Wartime Merchant Fleet and Post-war Shipping Requirements. The American Economic Review, 36 (2), 520-546.

Ramirez Perez, S. (2010). The European Committee for Economic and Social Progress: Business Networks Between Atlantic and European Communities. In W. Kaiser, B. Leucht, \& M. Gehler (Eds.), Transnational Networks in Regional Integration (pp. 61-84). Basingstoke: Palgrave.

Ratcliffe, M. (1985). Liquid Gold Ships: A History of the Tanker, 1859-1984. London: Lloyd's of London Press.

Rollings, N., \& Kipping, M. (2008). Private Transnational Governance in the Heyday of the Nation-State: The Council of European Industrial Federations (CEIF). Economic History Review, 61(2), 409-431.

Sawyer, L. S., \& Mitchell, W. H. (1973). The Liberty Ships. Devon: Newton Abbot.

Shields, J. (1986). The Invisible Billionaire: Daniel Ludwig. Boston: Houghton Mifflin.

Stopford, M. (1997). Maritime Economics. London: Routledge.

Tenold, S. (2019). Norwegian Shipping in the 20th Century: Norway's Successful Navigation of the World's Most Global Industry. Cham: Palgrave.

Tenold, S., Iversen, M. J., \& Lange, E. (Eds.). (2012). Global Shipping in Small Nations: Nordic Experiences After 1960. Basingstoke: Palgrave.

Theotokas, I., \& Harlaftis, G. (2009). Leadership in World Shipping: Greek Family Firms in International Business. Basingstoke: Palgrave.

Tsakas, C. (2018). Europeanisation Under Authoritarian Rule: Greek Business and the Hoped-for Transition to Electoral Politics, 1967-1974. Business History. https://doi.org/10.1080/00076791.2018.1494156.

Tzamtzis, A. (1984). The Liberties and the Greeks: The Chronicle of a Peaceful Fleet. Athens: Estia. [in Greek]. 
UNCTAD. (2017). Review of Maritime Transport.

Wend, H. B. (2001). Recovery and Restoration: U.S. Foreign Policy and the Politics of Reconstruction of West Germany's Shipbuilding Industry, 1945-1955. Westport, CT: Greenwood Publishing.

Open Access This chapter is licensed under the terms of the Creative Commons Attribution-NonCommercial-NoDerivatives 4.0 International License (http:// creativecommons.org/licenses/by-nc-nd/4.0/), which permits any noncommercial use, sharing, distribution and reproduction in any medium or format, as long as you give appropriate credit to the original author(s) and the source, provide a link to the Creative Commons license and indicate if you modified the licensed material. You do not have permission under this license to share adapted material derived from this chapter or parts of it.

The images or other third party material in this chapter are included in the chapter's Creative Commons license, unless indicated otherwise in a credit line to the material. If material is not included in the chapter's Creative Commons license and your intended use is not permitted by statutory regulation or exceeds the permitted use, you will need to obtain permission directly from the copyright holder. 